\title{
The Toxic Laundry Detergent Powder 'Prinso' Is Gaining Notoriety Amongst Villagers For Deliberate Self- Poisoning In And Around The Matara District
}

\author{
MAAK Munasinghe*, W.K.B.K.M.Fernando* \\ *General Hospital Matara, Sri Lanka
}

\begin{abstract}
Introduction: The washing powder 'Prinso' consists of 2 sachets, one containing pink crystals and the other white granules which has become a popular agent amongst the youth for self poisoning.

Objectives: To document clinical and biochemical features of 'prinso' poisoning.

To analyze the chemical constituents of prinso.

Patients and methods: We present a series of 7 patients who were admitted to General hospital Matara following 'Prinso' poisoning, from 01.062006 to 01.10 .2007 . We chemically analyzed the two sachets in faculty of science university of Ruhuna.

Results: The male: female ratio was 3:4.0ut of the 7 patients, 1 patient developed acute renal failure.

Conclusion: The readily available household product 'Prinso' has come to recognition in the array of poisons responsible for deliberate self poisoning among young with a preponderance among females ingesting it in the southern province of Sri Lanka.
\end{abstract}

\section{Introduction}

Sri Lanka ranks first among South-East Asian countries with respect to commitment of suicide, the majority of which are due to ingestion of paraquat, yellow oleander and organophosphorus compounds ${ }^{1,2,3}$. Yellow oleander poisoning is common in the north-central province ${ }^{4,5}$. Similarly, deliberate ingestion of household products is a popular method of self poisoning in rural areas of the southern province. The toxic laundry detergent powder 'prinso' is gaining notoriety amongst villagers for deliberate self poisoning in and around the districts of Galle and Matara (personal data). 'Prinso' is manufactured by small scale entrepreneurs and consists of 2 sachets (figure 1). They are also sold under other trade names such as 'Prinso', 'Ever Light', 'Vihanga' and 'Diamond Light'.

\section{Patients and Methods}

General hospital Matara is a primary health care centre for about 761,236people living in the Matara district and one of the tertiary referral center for about 22,78,271 people living in the southern province of Sri Lanka. This is a retrospective \& descriptive study, using BHTs of patients who admitted to ward 26 and 17 in general hospital Matara. Exposure was confirmed by positive identification of the product labels.

Two sachets were chemically analyzed quantitatively and qualitatively in the department of chemistry university of 'Ruhuna' (Table 1).

\section{Results}

There were seven patients in the sample. Out of them 6 patients had burning epigastric pain, nausea \& vomiting. Two patients had loose stools. Vertigo, blurred vision, reduced urine output, cough \& body weakness were reported from a single patient.

Correspondence: Dr W.K.B.K.M.Fernando, General Hospital, Matara, Sri Lanka.

Email: kasunfernando45@gmail.com 
Following ingestion high systolic blood pressure was noticed in 2 patients. Out of the 7 patients, 1 patient developed acute renal failure. No significant complication regarding respiratory system or no impairment in liver functions were noticed with in the study sample.

This laundry detergent is marketed as two sachets (figure 1), containing $1.2 \mathrm{~g}$ of $100 \%$ Potassium permanganate $\left(\mathrm{KMNO}_{4}\right)$ and 12.5g of Oxalic Acid 70\% (OA) (Table 1).

\section{Discussion}

Acute ingestion of large amounts (high concentrations) of oxalic acid or its soluble salts can produce immediate corrosive effects on the mucous membranes of the upper GI tract giving rise to severe epigastric pain, hemorrhagic gastritis ${ }^{6}$ and hematemesis.

Once absorbed into the system oxalates combine with almost all of the ionized calcium producing insoluble calcium oxalate which is deposited in the kidneys, liver and other tissues causing serious systemic damage7. Muscle twitching, cramps and CNS depression may occur initially leading to muscular fasciculations, tetany, seizures, drowsiness, stupor, coma, ECG changes such as QT interval prolongation, variable conduction defects and/or cardiac arrest ${ }^{8,9,10}$, due to profound hypocalcaemia. The quoted oral rat LD50 for oxalic acid is $7500 \mathrm{mg} / \mathrm{kg}$ and the estimated mean lethal adult dose is about 15-30g6. Potassium permanganate [(permanganic acid/ potassium salt), CAS 7722-64-7] is an antiseptic and astringent agent with powerful oxidizing effects. The estimated lethal adult dose is about $10 \mathrm{~g}^{10}$.

The crystalline and concentrated forms are corrosive due to the release of potassium hydroxide when in contact with water. Ingestion may result in caustic injury to the mouth and gastrointestinal tract, as well as upper airway oedema causing chest tightness and coughing. Potassium permanganate may oxidize ferrous $\left(\mathrm{Fe}^{2+}\right)$ to ferric $\left(\mathrm{Fe}^{3+}\right)$ haemoglobin (MetHb) which is incapable of carrying oxygen effectively, altering the shape of the oxygenhaemoglobin dissociation curve leading to functional anaemia and cellular hypoxia. Symptoms may arise depending on the concentration of MetHb in blood. Patients with $<15 \%$ MetHb levels are usually asymptomatic. Those with $15-20 \%$ may experience cyanosis with mild symptoms, $20-45 \%$ marked cyanosis with moderate symptoms, $45-70 \%$ severe cyanosis and severe symptoms. MetHb levels of $>70 \%$ usually indicate a lethal outcome. Hemolysis maybe induced with formation of Heinz bodies, particularly in patients with low tolerance of oxidative stress ${ }^{8}$.

Renal failure associated with $\mathrm{OA}$ ingestion is most likely due to a tubular

\section{Table 1. Report on Chemical Composition of a Washing Powder}

\begin{tabular}{|c|c|c|c|c|}
\hline Sachet & $\begin{array}{l}\text { Chemical } \\
\text { Composition }\end{array}$ & Qualitative Test & Quantity & $\begin{array}{l}\text { Quantitative } \\
\text { Test }\end{array}$ \\
\hline White & $\begin{array}{l}\text { Oxalic acid } \\
\left(\mathrm{H}_{2} \mathrm{C}_{2} \mathrm{O}_{4}\right)\end{array}$ & $\begin{array}{l}\text { 1. Conc. } \mathrm{H}_{2} \mathrm{~S}_{2} \mathrm{O}_{4} \text { and lime } \\
\text { water test. } \\
\text { 2. } \mathrm{AgNO}_{3} \text { test } \\
\text { 3. } \mathrm{CaCl}_{2} \text { test } \\
\text { 4. } \mathrm{MnSO}_{4}, \mathrm{NaOH} \text { and dil. } \\
\mathrm{H}_{2} \mathrm{SO}_{4} \text { test }\end{array}$ & $\begin{array}{l}70 \% \mathrm{H}_{2} \mathrm{C}_{2} \mathrm{O}_{4} \text { (Rest of } \\
\text { the } 30 \% \text { could be } \\
\text { crystalline water since } \\
\text { oxalic acid crystals } \\
\text { exit as } \mathrm{H}_{2} \mathrm{C}_{2} \mathrm{O}_{4} \cdot 2 \mathrm{H}_{2} \mathrm{O} \text { ) }\end{array}$ & $\begin{array}{l}\text { Titration } \\
\text { against } \mathrm{KMnO}_{4}\end{array}$ \\
\hline Dark Magenta & $\begin{array}{l}\text { Potassium } \\
\text { permanganate } \\
\left(\mathrm{KMnO}_{4}\right)\end{array}$ & $\begin{array}{l}\text { 1. } \mathrm{H} 2 \mathrm{O} 2 \text { and dil. } \mathrm{H}_{2} \mathrm{SO}_{4} \\
\text { test. } \\
\text { 2. Dil. } \mathrm{HCl} \text { and } \mathrm{H}_{2} \mathrm{~S} \text { test } \\
\text { 3. } \mathrm{FeSO}_{4} \text { and dil. } \mathrm{H}_{2} \mathrm{SO}_{4} \\
\text { test }\end{array}$ & $100 \% \mathrm{KMnO}_{4}$ & $\begin{array}{l}\text { Titration } \\
\text { against } \mathrm{H}_{2} \mathrm{C}_{2} \mathrm{O}_{4}\end{array}$ \\
\hline
\end{tabular}


defect as the majority improved with supportive care. Konta et al reported a case of reversible renal tubular dysfunction with electron microscopic evidence of deposition of oxalate crystals in the tubular epithelium ${ }^{11}$.

\section{Conclusion}

In our study no patients required dialysis or any organ supportive therapy and no deaths. However a larger sample is necessary to study the effects and field study will helped to find out the reason, why these people used to take this as a method for suicide.

\section{Acknowledgments}

We would like to acknowledge Dr.T.M.U.Liyanage, Research Assisstant and Prof.Pathirana, Head of the Department, Department of Chemistry, University of Ruhuna and Dr.Mrs.M. Edussuriya, Senior Lecturer, Department of Chemistry, University of Ruhuna for analyzing this washing powder.

\section{References}

1. Eddleston M, Gunnell D, Karunaratne A, de Silva D, Sheriff MH, Buckley NA. Epidemiology of intentional selfpoisoning in rural Sri Lanka. Br J Psychiatry 2005;187:583-4.

2. Michael Eddleston, Lakshman Karalliedde, Nick Buckley, Ravindra Fernando, Gerard Hutchinson et al. Pesticide poisoning in the developing world-a minimum pesticide list. The Lancet 2002;360:1163-1167

3. M. EDDLESTON. Patterns and problems of deliberate self poisoning in the developing world. QJ Med 2000;93:715-731

4. M Eddleston, CA Ariaratnam, WP Meyer, G Perera, AM Kularatne et al. Epidemic of self-poisoning with seeds of the yellow oleander tree (Thevetia peruviana) in northern Sri Lanka. Tropical Medicine and International Health 1999; 4: 266-73

5. Epidemiology of poisoning in $\mathrm{GH}$ Anuradhapura and GH Polonnauwa in 2005. Newsletter North Central Province Clinical units. South Asian
Clinical Toxicology Research Collaboration 2006;1:1

6. MICROMEDEX® Healthcare Series : Document; POISINDEX® Managements; OXALIC ACID. Available from

http://proxy1.use.hcn.com.au/hcs/libr arian/PFDefaultActionId/pf.PrintReady

7. Zarembski PM, Hodgkinson A. Plasma oxalic acid and calcium levels in oxalate poisoning. Journal of Clinical Pathology 1967;20:283-85

8. Kent RO, Ilene BA, Neal LB et al. Poisoning \& drug overdose. 5 th ed. San Francisco, USA: McGraw-Hill Companies, 2007: 110-11,158,296-7.

9. MICROMEDEX® Healthcare Series : Document; POISINDEX® Managements; POTASSIUM PERMANGANATE. Available from http://proxy1.use.hcn.com.au/hcs/librari an/PFDefaultActionld/pf.PrintReady

10. Fernando Ravindra. Management of Poisoning. (Third revised edition). National Poisoning Information Centre, National Hospital of Sri Lanka. 2007; 149-150.

11. Konta T, Yamaoka M, Tanida $H$, Matsunaga T, Tomoike H. Acute renal failure due to oxalate ingestion. Intern Med 1998;37(9):762-5 